\title{
Assessment transition of exercise and dietary habit of athletes before and during ramadan in the pandemic of Covid-19
}

\author{
Toni Kurniawan ${ }^{1}$, Yetty Septiani Mustar ${ }^{2 *}$, Agus Hariyanto ${ }^{3}$, Indra Himawan Susanto ${ }^{4}$, Anna \\ Noordia $^{5}$ \\ 1,2,4,5 Department of Health Education and Recreation, Universitas Negeri Surabaya, Surabaya, 60213, Indonesia \\ ${ }^{3}$ Department of Sport Coaching Education, Universitas Negeri Surabaya, Surabaya, 60213, Indonesia \\ Corresponding author: yettymustar@unesa.ac.id
}

\begin{abstract}
This study aims to identify the training transitions and dietary habits of volleyball athletes' before and during Ramadan in the Covid-19 pandemic. The research design used is descriptive quantitative with a sample of 12 male junior volleyball athletes in the academy Sidoarjo volleyball. The results showed that most athletes experienced a decrease in the frequency of exercise during the month of Ramadan, especially during the COVID-19 pandemic. A total of 33.3\% of athletes maintained their exercise frequency, and $66.7 \%$ experienced a decrease in exercise frequency. Furthermore, during Ramadan and Covid-19, there was an increase in the frequency of eating 1-2 times a day (58.4\%), snack consumption (50\%), fruit and vegetables (75\%), fried foods 4-7 times a week (8.4\%), instant noodles 1-3 times a week (25\%) and fast food 1-3 times a week (8.4\%) in athletes. Concerning this, it is imperative to revitalize the program and monitor the athlete's training periodically, which is adjusted to the conditions of the COVID-19 pandemic and provide a dietitian to regulate the athlete's diet to obtain a balanced nutritional intake following the exercise portion.
\end{abstract}

Keywords: exercise; dietary habit; ramadan; pandemic; covid-19

\section{Assessment transisi latihan dan pola makan atlet sebelum dan saat ramadan di masa pandemi Covid-19}

\begin{abstract}
Abstrak
Tujuan dari penelitian ini adalah untuk mengidentifikasi transisi latihan dan pola makan atlet bola voli sebelum dan saat ramadan di masa pandemi Covid-19. Desain penelitian yang digunakan yaitu deskriptif kuantitatif dengan sampel 12 atlet laki-laki bola voli junior yang masih aktif dalam menjalani pemusatan latihan di Akademi Bola Voli Indomaret Sidoarjo. Hasil penelitian menunjukkan bahwa mayoritas atlet mengalami penurunan frekuensi latihan saat ramadan khususnya di masa pandemi covid-19. Sebanyak $33,3 \%$ yang mampu mempertahankan frekuensi latihan dan 66,7\% mengalami penurunan frekuensi latihan. Selanjutnya, saat ramadan dan Covid-19 terjadi peningkatan frekuensi makan 1-2 sehari $(58,4 \%)$, konsumsi camilan $(50 \%)$, buah dan sayuran $(75 \%)$, gorengan $4-7$ kali dalam seminggu $(8,4 \%)$, mie instant $1-3$ kali dalam satu minggu (25\%) serta makanan cepat saji $1-3$ kali dalam seminggu $(8,4 \%)$ pada atlet. Berdasarkan hal ini, maka sangat penting untuk melakukan revitalisasi program dan pemantauan latihan atlet secara berkala yang disesuaikan dengan masa pandemi covid-19 dan menyediakan dietisien untuk pengaturan makan atlet agar dapat memperoleh asupan gizi seimbang sesuai dengan porsi latihannya.
\end{abstract}

Kata Kunci: latihan; dietary habit; ramadan; pandemic; covid-19 


\section{PENDAHULUAN}

Olahraga bermanfaat meningkatkan kekuatan pada otot, manajemen berat badan, membantu dalam kebugaran, dan memperbaiki kelentukan sendi (Kemenkes, 2018). Latihan fisik atau olahraga dapat diartikan sebagai aktivitas fisik yang terencana, terstruktur, dan gerakan berulang untuk memperbaiki atau menjaga kebugaran tubuh (Welis, Wilda and Sazeli, 2013). Latihan fisik terus menerus menentukan atlet dalam mempertahankan keseimbangan antara asupan makanan dengan energi yang dikeluarkan dan tuntutan tambahan dalam jumlah tinggi saat latihan (Mielgo-Ayuso et al., 2015). Selain latihan, atlet juga sangat perlu memperhatikan pola makan untuk menambah kebutuhan gizi yang seimbang dengan energi yang dibutuhkan. Gizi tidak hanya berhubungan dengan kesehatan saja tetapi juga berhubungan dengan perkembangan otak, kemampuan belajar, produktivitas kerja, disebabkan karena dari aktivitas kinerja energi pada otot atlet jauh lebih tinggi (Adriani \& Wiratmadji, 2012). Pola makan atlet merupakan hal yang sangat penting untuk pemenuhan zat-zat gizi yang digunakan sebagai sumber energi, unsur zat makanan juga digunakan sebagai keseimbangan gizi pada tubuh (Malonda, Dinarti, \& Pangastuti, 2012). Aspek khusus pemenuhan gizi atlet seperti jenis olahraga, program latihan yang berbeda dari populasi pada umumnya harus dipertimbangkan (Mielgo-Ayuso et al., 2015). Oleh karena itu, pemilihan makanan yang kaya nutrisi juga penting untuk mengurangi resiko kekurangan nutrisi yang dapat mengganggu kesehatan dan performa, terutama ketika asupan energi terbatas mengurangi massa tubuh/massa lemak (Larson-Meyer, Woolf, \& Burke, 2018).

Ramadan adalah bulan bagi umat muslim yang menawarkan perbuatan holistik dalam kehidupan, termasuk kebiasaan diet, pola tidur, cara hidup sehari-hari, kegiatan sosial, dan perubahan pola makan dalam bentuk pengurangan frekuensi asupan makanan, cairan, dan meningkat kecenderungan untuk mengonsumsi makanan berkalori tinggi dan minuman (Memari et al., 2011). Pengaturan latihan atlet saat bulan ramadan sangat penting untuk dilakukan untuk tetap menjaga kebugaran serta mempertahankan kondisi fisik atlet. Mempertahankan untuk tetap berolahraga selama bulan ramadan umumnya banyak membahas tentang intensitas dan waktu yang tepat untuk berolahraga (Puspitawati, 2019). Penelitian telah menunjukkan bahwa puasa selama 30 hari berturut-turut tanpa olahraga dapat mengalami penurunan kekuatan dan kebugarannya (Noorbhai, 2013). Sehingga, dalam menjalankan latihan saat bulan ramadan merupakan hal yang sangat penting untuk menjaga dan mengoptimalkan performa atlet (Puspitawati, 2019). Selain itu, memenuhi asupan pada pola makan atlet junior saat bulan ramadan tentu berbeda, saat bulan ramadan atlet yang menjalankan ibadah puasa, hanya mendapat asupan pada pagi hari (sahur) dan malam hari setelah berbuka puasa.

Bulan ramadan pada tahun ini mengalami perbedaan dengan sebelumnya, karena pada ramadan pada tahun 2020 terjadi pandemi Covid-19 yang mengakibatkan adanya batasan untuk melakukan aktifitas secara bersama, menjaga jarak, dan mengimplementasikan protokol kesehatan (Astutik, 2020). Covid-19 merupakan virus menular yang disebabkan oleh acute respiratory syndrome coronavirus 2 atau SARS-CoV-2 yang lebih dikenal dengan sindrom pernapasan akut corona virus 2 (Lai et al., 2020). Wabah penyakit ini pertama kali ditemukan di Wuhan, Hubei, China pada tahun 2019, jenis virus yang diberi nama corona virus disase2019 atau dikenal dengan covid-19 telah menyebar secara luas diberbagai negara termasuk di Indonesia (Djalante et al., 2020). Covid 19 dapat menular dari manusia ke manusia melalui percikan batuk/bersin (droplet). Penyakit ini dapat menyebar dari orang ke orang melalui tetesan kecil dari hidung atau mulut yang menyebar saat pandemi Covid-19 batuk atau mengeluarkan napas, tetesan ini mendarat di benda dan permukaan disekitar orang tersebut, orang lain kemudian tertular Covid-19 dengan menyentuh benda atau permukaan, lalu menyentuh mata hidung, atau mulut. Virus dapat bertahan diudara hingga 3 jam dan diberbagai permukaan hingga 72 jam (Hughes et al., 2020). 
Pandemi covid-19 memberikan perubahan kebiasaan dalam kehidupan sehari-hari, terutama penyesuaian dalam setiap kebijakan yang telah dibuat oleh pemerintah untuk mengatasi penyebaran virus yang lebih besar (Kompas, 2020). Pandemi juga telah memicu perubahan di semua aspek kehidupan sehari-hari, kesehatan, mental, sampai dengan perencanaan kegiatan olahraga (Stearns et al., 2020). Berbagai kejuaraan atau kompetisi nasional maupun internasional terpaksa harus ditunda hingga batas waktu yang tidak dapat ditentukan hingga masa pandemi covid-19 berakhir (CNN, 2020; Mitra, 2020). Pandemi juga mengakibatkan pemusatan latihan pada akademi bola voli indomaret Sidoarjo dihentikan. Hal ini mengakibatkan atlet harus menjalani latihan secara individu atau Traning from home (TFH) dan pengaturan makanan secara mandiri karena adanya pemberlakuan pembatasan kegiatan selama pandemi. Oleh karena itu, penyesuaian dalam program latihan serta pola makan merupakan faktor penting untuk atlet selama menjalankan latihan secara mandiri saat bulan ramadan terutama ditengah situasi pandemi. Penelitian yang dilakukan oleh Chaouachi et al (2012) membuktikan bahwa bulan ramadan dapat mempengaruhi performa atlet karena adanya pembatasan energi, kurang tidur, gangguan ritme sirkadian, dehidrasi, dan perubahan beban latihan. Selain itu, Ramadan juga menyebabkan periode yang lama tanpa asupan nutrisi dan ketidakfleksibelan dengan waktu makan dan minum sepanjang hari, sehingga sebagian besar atlet tidak dapat memenuhi kebutuhan nutrisi secara keseluruhan, atau untuk memberikan dukungan nutrisi khusus untuk sesi latihan, yang dapat mempengaruhi performa atlet dan mengurangi efektivitas latihan dan pemulihan (Burke \& King, 2012). Mengacu dari hal tersebut, maka sangat penting untuk mengidentifikasi transisi latihan dan pola makan atlet bola voli indomaret Sidoarjo baik sebelum dan saat ramadan sebagi bahan acuan dalam mengembangkan kebijakan, program latihan yang tepat, dan pengaturan pola makan atlet sesuai dengan kebutuhan nutrisi berdasarkan aktivitas latihan yang dilakukan khususnya di masa pandemi covid-19.

\section{METODE}

Penelitian ini menggunakan jenis deskriptif kuantitatif yang untuk mendeskripsikan transisi latihan dan pola makan pada atlet laki-laki bola voli Sidoarjo. Sampel dalam penelitian ini sebanyak 12 atlet junior putra Sidoarjo dengan kriteria inklusi beragama islam, menjalankan ibadah puasa dan aktif melakukan latihan. Instrumen penelitian untuk mengidentifikasi program latihan yang dilakukan oleh atlet menggunakan kuesioner program latihan yang diadaptasi dari penelitian Rizal et al (2018) dan untuk pola makan atlet menggunakan instrumen food frequency yang dikembangkan dari penelitian Ramadani (2017) dan Niswah (2016). Analisis data dilakukan secara deskriptif untuk memperoleh gambaran transisi latihan serta pola makan atlet sebelum ramadan dan pada saat selama masa pandemi covid-19 dengan menggunakan aplikasi Statistical Program for Social Sciences (SPSS) versi 25 .

\section{HASIL DAN PEMBAHASAN}

\section{Transisi latihan}

Aspek fisik merupakan salah satu faktor yang paling penting dalam menentukan prestasi diberbagai cabang olahraga dan kebutuhan aspek fisik pada seorang atlet (Kartiko \& Tuasikal, 2020). Menjadikan atlet junior bola voli yang berkualitas dan memiliki fisik kuat, maka diperlukan latihan yang terprogram. Masa pandemi covid-19 tidak hanya memberi dampak pada pola latihan, namun juga berimplikasi pada aspek psikologis, pola hidup, tidur dan gizi atlet (Tayech et al., 2020). Atlet junior bola voli Sidoarjo melakukan kegiatan pemusatan latihan pada saat ramadan dan covid-19 dengan pemusatan latihan traning from home, atau dapat dikatakan secara informal jaga jarak (physical distancing). Bagi atlet, latihan menjadi kebutuhan yang harus dilakukan meskipun saat ramadan maupun saat pandemi. Tabel 
1 menunjukkan bahwa adanya transisi waktu latihan atlet bola voli junior Sidoarjo. Sebelum ramadan lebih dari $83 \%$ atlet berlatih pada pagi hari, dan saat ramadan di masa pandemi covid19 atlet cenderung memilih untuk menjadikan 2 sesi latihan pagi dan sore hari.

Tabel 1. Transisi waktu latihan sebelum dan saat ramadan dimasa pandemi COVID-19

\begin{tabular}{lcccc}
\hline \multirow{2}{*}{ Waktu Latihan } & \multicolumn{2}{c}{ Ramadan dan Covid-19 } & \multicolumn{2}{c}{ Saat Ramadan dan Covid-19 } \\
\cline { 2 - 5 } & $\mathrm{n}$ & $\%$ & $\mathrm{n}$ & $\%$ \\
Pagi & 10 & 83,3 & 0 & 0 \\
Sore & 0 & 0 & 3 & 25 \\
Pagi dan Sore & 2 & 16,7 & 9 & 75 \\
\hline
\end{tabular}

Selanjutnya, transisi frekuensi atlet yang ditampilkan pada gambar 1 menunjukkan bahwa mayoritas responden mengalami penurunan latihan pada saat ramadan dan covid-19, dari 12 responden hanya 4 responden yang dapat mempertahankan frekuensi latihan pada saat ramadan dan covid-19.

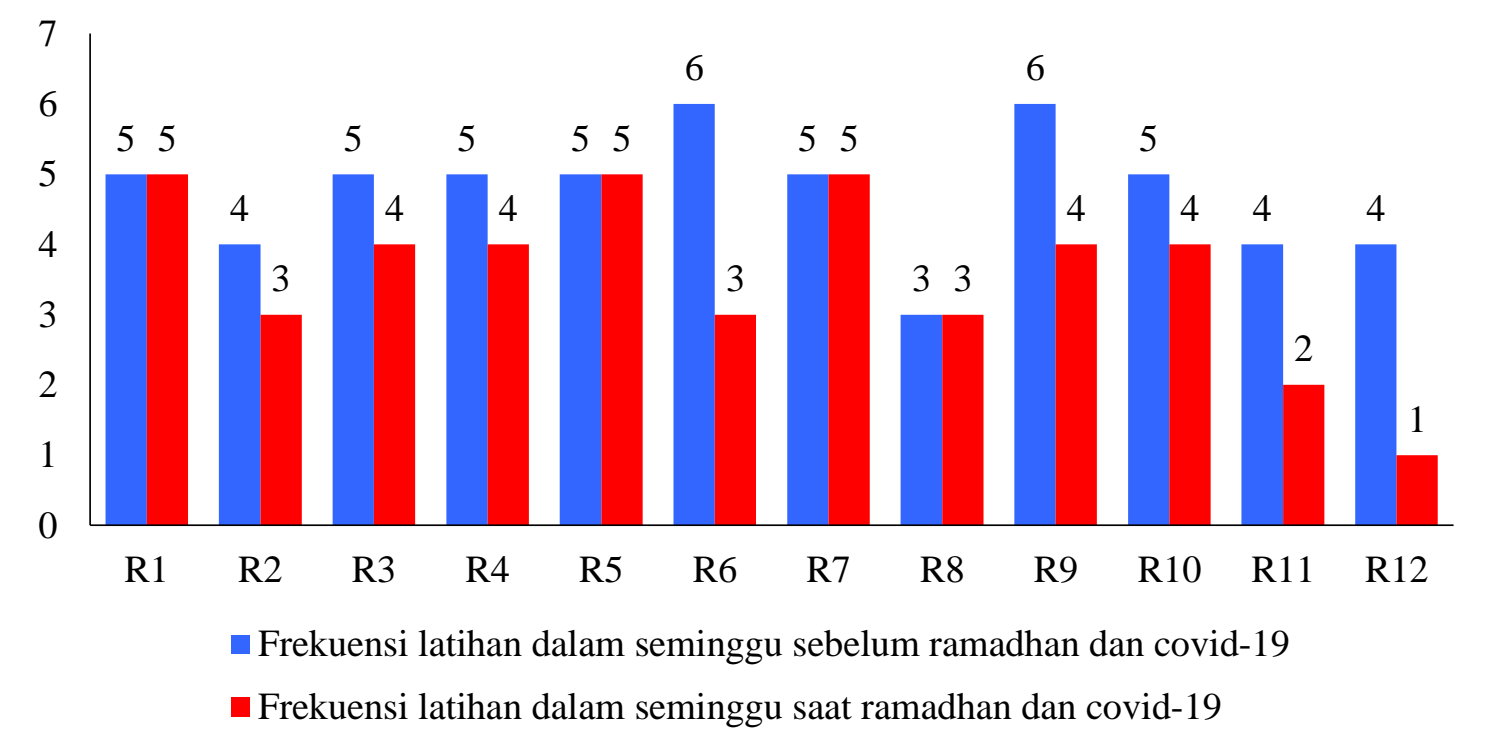

Gambar 1. Transisi Frekuensi Latihan Atlet

Adanya perubahan pada transisi latihan menyebabkan ruang gerak dari atlet saat latihan sangatlah terbatas, pembatasan ini dikarenakan pada masa pandemi berlakunya peraturan Pembatasan Sosial Berskala Besar (PSBB), untuk mencegah kemungkinan penyebaran penyakit atau terkontaminasinya covid-19. Keterbatasan dari pelatih yang tidak dapat memantau secara langsung latihan yang dilakukan oleh atlet juga menjadi salah satu alasan perbedaan transisi latihan selama bulan ramadan dan pandemi, terutama pada latihan fisik maupun teknik. Pada kualitas fisik terlihat secara nyata dan dapat dilakukan pengukuran terhadapnya, biasanya di represantasikan dengan tingkat kebugaran fisik, baik itu yang sifatnya kekuatan, ketahanan, kapasitas aerobik dan anaerobik yang prima serta keterampilanketerampilan spesifik yang dibutuhkan atlet pada cabang olahraga tertentu (Indra \& Wijayanti, 2015). Hal ini sejalan dengan peneliti lainnya yang menyatakan bahwa Covid-19 menjadi faktor berubahnya pada pola latihan atlet, oleh karena itu sangat dibutuhkan berbagai upaya yang dapat mendukung pelaksanaan latihan atlet, sumber daya, fasilitas, serta strategi yang tepat (Andreato, Coimbra, \& Andrade, 2020; Stambulova, Schinke, Lavallee, \& Wylleman, 2020).

Latihan dapat dikatakan sebagai tantangan nyata bagi atlet dalam menjalankan ibadah puasa Ramadan, terutama di masa pandemi covid-19 (Moghadam, Taati, Paydar Ardakani, \& 
Suzuki, 2021). Pada saat bulan ramadan atlet yang melaksanakan ibadah puasa tidak mengonsumsi makanan selama berjam-jam sebelum dan selama latihan yang berkontribusi pada penurunan kadar endogen secara paralel dengan dehidrasi yang berlanjut hingga akhir latihan (Shephard, 2012). Selain itu, kantuk di siang hari, dan perasaan malaise (lelah, tidak nyaman, dan kurang enak badan) yang meningkat serta kelesuan adalah faktor yang dapat mempengaruhi atlet muslim terhadap perubahan suasana hati yang tidak diinginkan (Lim, Damit, \& Aziz, 2014; Shephard, 2012). Oleh karena itu, atlet yang berpuasa pada bulan ramadan dapat mengalami tingkat kelelahan yang relatif lebih tinggi bila dibandingkan dengan periode non-Ramadan (Aziz, Wahid, Png, \& Jesuvadian, 2010; Brisswalter et al., 2011; Lim et al., 2014).

Strategi latihan yang tepat diperlukan selama bulan ramadan untuk menjaga performa atlet junior dengan transisi latihan yang berbeda dengan sebelumnya. Banyak hal yang harus diperhatikan dalam menyusun program latihan yang baik pada bulan ramadan, seperti menentukan siapa yang akan menjalankan program latihan fisik, orang sehat yang menjaga kebugaran, orang dengan sakit diabet yang membutuhkan aktivitas fisik dan atlet. Hal tersebut dilakukan untuk mengatur frekuensi, intensitas, dan durasi latihan. Rizal et al (2018) merekomendasikan untuk melakukan latihan 2 kali dalam sehari selama bulan ramadan yang terdiri dari skill dan teknik yang menggunakan intensitas 50-70\% dari DNMax serta latihan peningkatan performa melalui latihan circuit training/resistance training (aerobic/anaerobic fitness) yang menggunakan intensitas 60 - 90\% dari DNMax, sedangkan untuk rekomendasi waktu dapat dipilih oleh atlet atau pelatih agar pelaksanaan latihan tidak mengganggu ibadah puasa.

Berbeda dengan latihan fisik untuk seorang atlet yang tujuannya lebih kompleks dari pada orang sehat dan orang dengan penyakit diabetes yaitu untuk menjaga dan meningkatkan performa serta latihan skill dan teknik, selama bulan ramadan banyak pelatih yang harus menyesuaikan waktu pelatihan dari siang sampai sore atau malam hari (Roy, Kuan, \& Tenenbaum, 2016). Perubahan sesi latihan terjadi pada seluruh atlet junior putra Indomaret Sidoarjo yang pada saat bulan ramadan lebih banyak dilakukan pada sore hari, selain latihan teknik terdapat latihan fisik yang bertujuan untuk menjaga atau meningkatkan performa juga bermanfaat untuk kekebalan imunitas atlet. Melakukan olahraga dengan intensitas sedang dapat meningkatkan kekebalan tubuh secara keseluruhan, namun melakukan olahraga yang intensif dan berkepanjangan dapat merusak kekebalan tubuh seseorang 72 jam setelah berolahraga (Wong et al., 2020). Transisi latihan atlet junior pada saat ramadan dan covid-19 memberikan pengaruh yang cukup besar bagi atlet maupun pelatih untuk dapat beradaptasi dengan berbagai kondisi yang dialami dalam program latihan serta mempertimbangkan kebutuhan gizi selama pandemi

\section{Transisi pola makan atlet}

Makronutrien, mikronutrien, dan cairan dalam jumlah yang tepat sangat penting untuk menyediakan energi untuk pertumbuhan dan aktivitas. Untuk mengoptimalkan performa, atlet muda perlu mempelajari apa, kapan dan bagaimana cara makan dan minum sebelum, selama dan sesudah beraktivitas (Purcell, 2013). Pandemi covid-19 yang sedang berlangsung telah menghadirkan tantangan yang signifikan bagi para atlet mengenai kebiasaan latihan dan pengaturan nutrisi atlet (Aini \& Kemala, 2021). Hasil penelitian terkait karakteristik eating habits atlet bola voli junior Sidoarjo pada tabel 2 menunjukkan bahwa saat ramadan dan covid19 terjadi peningkatan frekuensi makan 1 - 2 kali sehari dari 8,3\% menjadi $66,7 \%$, konsumsi camilan dari $33,3 \%$ menjadi 83,3 , buah dan sayuran dari $8,3 \%$ menjadi $83,3 \%$, konsumsi susu 1-3 kali dalam seminggu dari $25 \%$ menjadi $33,3 \%$. Hasil ini selaras dengan temuan penelitian yang dilakukan oleh Nachvak (2019) yang menunjukkan terjadinya perubahan pola konsumsi makanan, khususnya peningkatan konsumsi produk susu seperti susu murni, yoghurt, dan keju. 
MEDIKORA, Vol. 20 No. 2 Oktober 2021 - 118

Toni Kurniawan, Yetty Septiani Mustar, Agus Hariyanto, Indra Himawan Susanto, Anna Noordia

Tabel 2. Karakteristik eating habits sebelum dan saat ramadan di masa pandemi Covid-19

\begin{tabular}{|c|c|c|c|c|}
\hline \multirow[t]{2}{*}{ Karakteristik Eating Habits } & \multicolumn{2}{|c|}{$\begin{array}{c}\text { Sebelum Ramadan } \\
\text { dan Covid-19 }\end{array}$} & \multicolumn{2}{|c|}{$\begin{array}{c}\text { Saat Ramadan } \\
\text { dan Covid-19 }\end{array}$} \\
\hline & $\mathrm{n}$ & $\%$ & $\mathrm{n}$ & $\%$ \\
\hline \multicolumn{5}{|l|}{ Frekuensi makan dalam sehari } \\
\hline $1-2 \times$ sehari & 1 & 8,3 & 8 & 66,7 \\
\hline $3-4 \times$ sehari & 11 & 91,7 & 4 & 33,3 \\
\hline \multicolumn{5}{|l|}{ Konsumsi camilan } \\
\hline $1-2 \times$ sehari & 4 & 33,3 & 10 & 83,3 \\
\hline $3-4 \times$ sehari & 8 & 66,7 & 2 & 16,7 \\
\hline \multicolumn{5}{|l|}{ Konsumsi buah dan sayuran } \\
\hline $1-3 \times$ seminggu & 1 & 8,3 & 4 & 33,3 \\
\hline $4-7 \times$ seminggu & 11 & 91 & 8 & 66,7 \\
\hline \multicolumn{5}{|l|}{ Konsumsi daging seminggu } \\
\hline $1-3 \times$ seminggu & 6 & 50 & 6 & 50 \\
\hline $4-7 \mathrm{x}$ seminggu & 6 & 50 & 6 & 50 \\
\hline \multicolumn{5}{|l|}{ Konsumsi air mineral sehari } \\
\hline $1-4$ gelas & 0 & 0 & 1 & 8,3 \\
\hline $5-8$ gelas & 12 & 100 & 11 & 91,7 \\
\hline \multicolumn{5}{|l|}{ Konsumsi susu dalam seminggu } \\
\hline $1-3 \mathrm{x}$ seminggu & 3 & 25 & 4 & 33,3 \\
\hline $4-7 \mathrm{x}$ seminggu & 9 & 75 & 8 & 66,7 \\
\hline \multicolumn{5}{|l|}{ konsumsi makan gorengan } \\
\hline $1-3 \mathrm{x}$ seminggu & 5 & 41,7 & 4 & 33,3 \\
\hline $4-7 \mathrm{x}$ seminggu & 7 & 58,3 & 8 & 66,7 \\
\hline \multicolumn{5}{|l|}{ Sarapan/sahur pada pagi hari } \\
\hline Iya & 10 & 83,3 & 12 & 100 \\
\hline Tidak & 2 & 16,7 & 0 & 0 \\
\hline \multicolumn{5}{|l|}{ Menu sarapan dominasi karbohidrat } \\
\hline Iya 1 & 11 & 91,7 & 10 & 83,3 \\
\hline Tidak & 1 & 8,3 & 2 & 16,7 \\
\hline \multicolumn{5}{|c|}{ Konsumsi makanan bekarbohidrat pada malam hari } \\
\hline $1-3 \mathrm{x}$ seminggu & 5 & 41,7 & 3 & 25 \\
\hline $4-7 \mathrm{x}$ seminggu & 7 & 58,3 & 9 & 75 \\
\hline \multicolumn{5}{|l|}{ Konsumsi suplemen atau vitamin } \\
\hline Iya & 4 & 33,3 & 2 & 16,7 \\
\hline Tidak & 8 & 66,7 & 10 & 83,3 \\
\hline \multicolumn{5}{|l|}{ Konsumsi mie instant } \\
\hline $1-3 \mathrm{x}$ seminggu & 8 & 66,7 & 11 & 91,7 \\
\hline $4-7 \mathrm{x}$ seminggu & 4 & 33,3 & 1 & 8,3 \\
\hline \multicolumn{5}{|l|}{ Konsumsi makanan cepat saji } \\
\hline $1-3 \mathrm{x}$ seminggu & 10 & 83,3 & 11 & 91,7 \\
\hline 4- $7 \mathrm{x}$ seminggu & 2 & 16,7 & 1 & 8,3 \\
\hline \multicolumn{5}{|l|}{ Konsumsi minuman bersoda } \\
\hline $1-3 \mathrm{x}$ seminggu & 12 & 100 & 10 & 83,3 \\
\hline 4- $7 \mathrm{x}$ seminggu & 0 & 0 & 2 & 16,7 \\
\hline \multicolumn{5}{|l|}{ Penambahan garam pada makanan } \\
\hline Iya & 5 & 41,7 & 3 & 25 \\
\hline Tidak & 7 & 58,3 & 9 & 75 \\
\hline
\end{tabular}

Selanjutnya, frekuensi konsumsi gorengan pada atlet yaitu $4-7$ kali dalam seminggu dari 58,3 menjadi $66,7 \%$, konsumsi makanan karbohidrat pada malam hari 4 - 7 kali dalam satu minggu dari 58,3\% menjadi $75 \%$, konsumsi mie instant 1 - 3 kali dalam seminggu dari $66,7 \%$ menjadi $91,7 \%$. Hal ini sejalan dengan penelitian lain dimana terjadi peningkatan konsumsi 
karbohidrat selama ramadan (Bakhotmah, 2011), kemudian konsumsi makanan cepat saji 1-3 kali seminggu dari 83,3\% menjadi $91,7 \%$ pada atlet. Oleh karena itu, mengkonsumsi makanan seimbang yang mengandung air, karbohidrat, biji-bijian, kacang-kacangan, buah-buahan, dan sayuran diperlukan untuk menjaga perlindungan dimasa pandemi covid-19 dan mengurangi peradangan akibat olahraga (Nieman \& Wentz, 2019; Suzuki, 2019). Pada konsumsi daging tidak mengalami perubahan baik pada sebelum ramadan serta saat ramadan dan covid-19 yaitu sebesar 50\%. Terjadi penurunan konsumsi air mineral dalam sehari sebanyak $5-8$ gelas dari 100\% menjadi 91,7\%, menu sarapan/sahur dominasi karbohidrat dari 91,7\% menjadi 83,3\% konsumsi suplemen/vitamin dari 33,3\% menjadi 16,7\%, padahal mengonsumsi zat gizi tambahan seperti vitamin A, vitamin D, dan zat besi diyakini dapat meningkatkan kekebalan dan mendukung tubuh melawan tantangan mendapatkan infeksi (Davison, Kehaya, \& Wyn Jones, 2016), sedangkan untuk konsumsi minuman bersoda dari 1 - 3 kali seminggu dari $100 \%$ menjadi $83,3 \%$, serta penambahan garam pada makanan dari $41,7 \%$ menjadi $25 \%$ saat ramadan dan covid-19. Perubahan pola makan atlet bola voli junior Sidoarjo dikarenakan atlet dihimbau untuk melakukan latihan di rumah masing-masing, sehingga makanan yang dikonsumsi atlet tidak dapat dipantau secara langsung oleh pelatih. Secara keseluruhan, berdasarkan hasil pengukuran eating dengan peneliti lainnya yang menyatakan bahwa pandemi covid-19 mempengaruhi pola makan atlet rugby dan atlet artistic swimming junior dikarenakan adanya peraturan lockdown, sehingga dikhawatirkan asupan nutrisi atlet tidak terpenuhi sesuai dengan kebutuhan atlet (Roberts, Gill, \& Sims, 2020; Russo, Fadda, \& Angioni, 2020).

Atlet junior atau dapat dikatakan usia remaja merupakan masa dimana pertumbuhan dan perkembangan pada titik yang maksimal (Nurdini \& Probosari, 2017). Sehingga, sangat perlu untuk memberikan perhatian terhadap pola makan atlet. Jumlah makanan yang dikonsumsi atlet junior pada saat bulan ramadan dan covid-19 mengalami penurunan. Asupan makanan yang seimbang dan terpenuhi dapat mempengaruhi performa seorang atlet (Pertiwi dan Murbawani, 2012). Bulan ramadan dan covid-19 mengharuskan atlet menjalankan program latihan secara individu dan beradaptasi dengan kondisi saat pandemi. Penelitian ini sejalan dengan penelitian Roberts et al (2020) yang mengungkapkan bahwa pandemi Covid-19 menghadirkan tantangan yang signifikan bagi para atlet mengenai kebiasaan makan atau pemenuhan nutrisinya, karena atlet yang biasanya mengonsumsi makanan sesuai dengan penatalaksanaan gizi di tempat pemusatan latihan, saat ini mengonsumsi makanan di rumah masing-masing tanpa pengawasan pelatih maupun tim gizi secara secara langsung.

Selanjutnya, persepsi atlet tentang pola makan pada gambar 2 menunjukkan bahwa hampir seluruh responden setuju sarapan pagi atau sahur dapat membantu fokus dalam latihan sebelum serta saat ramadan dan covid-19. Hasil penelitian yang dilakukan oleh Png et al (2014) bahwa mengonsumsi karbohidrat, protein, dan lemak dalam jumlah seimbang saat sahur dapat meningkatkan ketersediaan karbohidrat dan tingkat oksidasi karbohidrat selama sesi latihan. Kemudian, lebih dari $65 \%$ responden tidak mengkonsumsi suplemen maupun vitamin tambahan sebelum maupun saat ramadan dan covid-19. Padahal vitamin memiliki peran penting dalam banyak proses fisiologis, memiliki efek pada kesehatan secara keseluruhan, dan bahkan dapat mempengaruhi kinerja atletik (Thompson, Manore, \& Vaughan, 2017). Seluruh responden setuju bahwa sangat penting untuk selalu menjaga pola makan secara teratur serta pola makan dapat mempengaruhi pertumbuhan dan kesehatan baik sebelum ramadan dan covid19 serta saat ramadan dan covid-19. Oleh karena itu, menerapkan pola makan sehat dan memenuhi nutrisi memiliki dampak positif untuk meningkatkan sistem kekebalan tubuh selama karantina atau pembatasan sosial (Yousfi, Bragazzi, Briki, Zmijewski, \& Chamari, 2020). Kemudian, 91,70\% responden menyetujui bahwa pola makan dapat mempengaruhi energi saat latihan dan aktivitas lainnya sebelum maupun pada saat ramadan dan covid-19. Hal ini sesuai dengan penelitian yang dilakukan oleh (Shaw, Boyd, Burke, \& Koivisto, 2014) bahwa asupan 
makanan dan zat gizi makro yang cukup akan menunjang kebugaran, daya tahan kardiorespirasi, dan pemenuhan energi saat latihan.

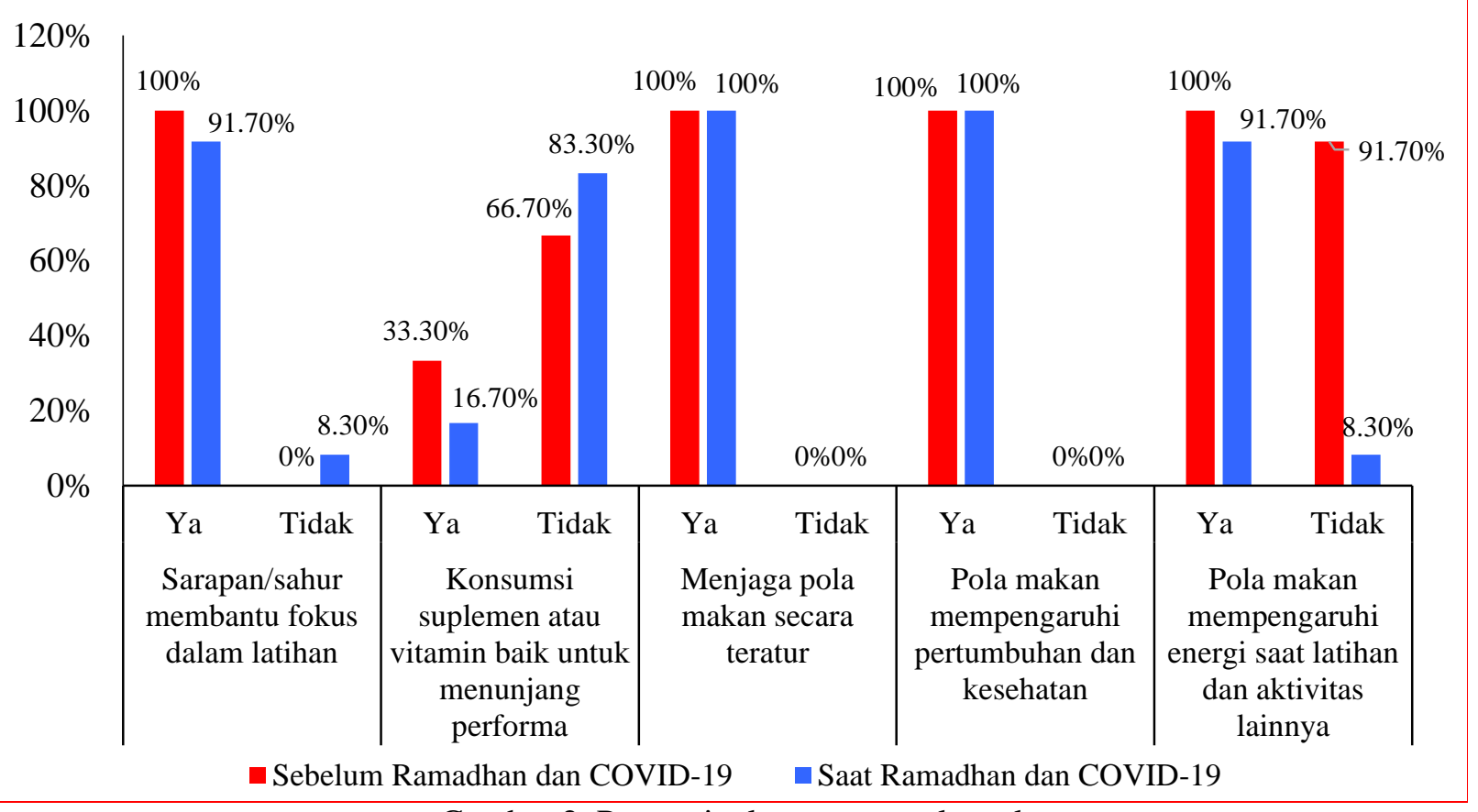

Gambar 2. Persepsi atlet tentang pola makan

Kebugaran dan kesehatan atlet junior diperhatikan melalui transisi latihan dan pola makan yang disesuaikan saat pandemi dan bulan ramadan untuk mendapatkan imunitas yang baik. Nutrisi dan hidrasi yang tepat sangat penting selama bulan ramadan, nutrisi yang direkomendasikan saat bulan ramadan adalah kandungan nutrisi yang terdiri dari karbohidrat 6 - 10 gram per $\mathrm{Kg}$ berat badan, protein 1,2 - 1,7 gram per Kg berat badan, dan lemak 20 - 30 $\%$ dari total energi yang digunakan selanjutnya untuk cairan yang masuk dalam tubuh minimal 3\% dari masa tubuh (Noorbhai, 2013). Memenuhi kebutuhan cairan saat latihan sangatlah peting bagi atlet, aturan yang direkomendasikan oleh WHO adalah minumlah air dalam jumlah yang banyak diantara waktu buka puasa dan sahur dan mengonsumsi hydrating food (semangka, strawberry, peach, timun, sop, dan hydrating food lainnya) selama bulan ramadan. Suhu udara yang tinggi juga dapat membuat seseorang berkeringat lebih banyak, sehingga penting untuk memenuhi asupan cairan untuk menggantikan cairan yang hilang pada siang hari saat berbuka setidaknya 10 gelas (WHO EMRO, 2020).

\section{SIMPULAN}

Transisi latihan atlet junior bola voli mengalami perbedaan pada saat ramadan dengan frekuensi latihan yang lebih rendah dibandingkan sebelum ramadan serta covid-19. Adanya pengaruh pada bulan ramadan dan pandemi covid-19 memberikan dampak yang besar bagi transisi latihan fisik atlet junior, dengan penerapan pembatasan sosial berskala besar yang mengakibatkan atlet berlatih tanpa pengawasan secara langsung dari pelatih, yang harus melakukan latihan secara individu selama pandemi covid-19. Selanjutnya, terdapat perubahan eating habits atau kebiasaan pola makan atlet pada jumlah konsumsi dan waktu konsumsi dikarenakan pada saat bulan ramadan atlet menjalankan ibadah puasa, akan tetapi jumlah yang diberikan pada konsumsi malam hari berbeda dengan sebelum ramadan, yaitu dengan jumlah konsumsi makanan yang lebih sedikit, namun di sisi lain terjadi peningkatan frekuensi makan, konsumsi camilan, buah dan sayuran, mie instant serta makanan cepat saji pada atlet. Perlunya revitalisasi program latihan dan pemantauan untuk atlet yang disesuaikan dengan masa pandemi covid-19, di samping melakukan pemantauan pola makan atlet secara berkala agar memperoleh asupan gizi seimbang sesuai dengan porsi latihannya. 
MEDIKORA, Vol. 20 No. 2 Oktober 2021 - 121

Toni Kurniawan, Yetty Septiani Mustar, Agus Hariyanto, Indra Himawan Susanto, Anna Noordia

\section{DAFTAR PUSTAKA}

Adriani, M., \& Wiratmadji, B. (2012). Pengantar Gizi Masyarakat. In Kencana Predana Media Group.

Aini, K., \& Kemala, A. (2021). The Nutritional Status of Athletes in the Athletics Branches of DKI Jakarta During the Covid-19 Period Based on Anthropometry. JUARA : Jurnal Olahraga, 6(1), 11-21. https://doi.org/10.33222/juara.v6i1.1028

Andreato, L. V., Coimbra, D. R., \& Andrade, A. (2020). Challenges to Athletes During the Home Confinement Caused by the COVID-19 Pandemic. Strength \& Conditioning Journal, 42(3), 1-5. https://doi.org/10.1519/SSC.0000000000000563

Astutik, Y. (2020). Di Tengah Pandemi COVID-19, Ini "Istimewanya" Ramadan 2020. Retrieved from https://www.cnbcindonesia.com/news/20200428105821-4-154885/ditengah-pandemi-covid-19-ini-istimewanya-ramadan-2020

Aziz, A. R., Wahid, M. F., Png, W., \& Jesuvadian, C. V. (2010). Effects of Ramadan fasting on 60 min of endurance running performance in moderately trained men. British Journal of Sports Medicine, 44(7), 516-521. https://doi.org/10.1136/bjsm.2009.070425

Bakhotmah, B. A. (2011). The puzzle of self-reported weight gain in a month of fasting (Ramadan) among a cohort of Saudi families in Jeddah, Western Saudi Arabia. Nutrition Journal, 10, 84. https://doi.org/10.1186/1475-2891-10-84

Brisswalter, J., Bouhlel, E., Falola, J. M., Abbiss, C. R., Vallier, J. M., Hausswirth, C., \& Hauswirth, C. (2011). Effects of Ramadan intermittent fasting on middle-distance running performance in well-trained runners. Clinical Journal of Sport Medicine: Official Journal of the Canadian Academy of Sport Medicine, 21(5), 422-427. https://doi.org/10.1097/JSM.0b013e3182293891

Burke, L. M., \& King, C. (2012). Ramadan fasting and the goals of sports nutrition around exercise. Journal of Sports Sciences, 30 Suppl 1, S21-31. https://doi.org/10.1080/02640414.2012.680484

Chaouachi, A., Leiper, J. B., Chtourou, H., Aziz, A. R., \& Chamari, K. (2012). The effects of Ramadan intermittent fasting on athletic performance: Recommendations for the maintenance of physical fitness. Journal of Sports Sciences, 30 Suppl 1, S53-73. https://doi.org/10.1080/02640414.2012.698297

CNN. (2020). PON Papua Kemungkinan Besar Ditunda karena Corona. Retrieved January 6, 2021, from https://www.cnnindonesia.com/olahraga/20200326152552-178487148/pon-papua-kemungkinan-besar-ditunda-karena-corona

Davison, G., Kehaya, C., \& Wyn Jones, A. (2016). Nutritional and Physical Activity Interventions to Improve Immunity. American Journal of Lifestyle Medicine, 10(3), 152-169. https://doi.org/10.1177/1559827614557773

Djalante, R., Lassa, J., Setiamarga, D., Sudjatma, A., Indrawan, M., Haryanto, B., ... Warsilah, H. (2020). Review and analysis of current responses to COVID-19 in Indonesia: Period of January to March 2020. Progress in Disaster Science, 6, 100091. https://doi.org/10.1016/j.pdisas.2020.100091 
Toni Kurniawan, Yetty Septiani Mustar, Agus Hariyanto, Indra Himawan Susanto, Anna Noordia

Hughes, D., Saw, R., Perera, N. K. P., Mooney, M., Wallett, A., Cooke, J., ... Broderick, C. (2020). The Australian Institute of Sport framework for rebooting sport in a COVID-19 environment. Journal of Science and Medicine in Sport. https://doi.org/10.1016/j.jsams.2020.05.004

Indra, E. N., \& Wijayanti, R. (2015). Outbound Sebagai Media Alternatif Untuk Meningkatkan Keterampilan Psikologis Pada Atlet. MEDIKORA, https://doi.org/10.21831/medikora.v0i1.4647

Kartiko, D. C., \& Tuasikal, A. R. S. (2020). The influences of foot run, brake runs, hop scotch, forward carioca for explosive power, agility, and speed in UNESA basketball male athlete. MEDIKORA, 19(2), 120-131. https://doi.org/10.21831/medikora.v19i2.35137

Kemenkes. (2018). Http://www.p2ptm.kemkes.go.id/infographic-p2ptm/hipertensi-penyakitjantung-dan-pembuluh-darah/manfaat-aktivitas-fisik.

Kompas. (2020). Upaya dan Kebijakan Pemerintah Indonesia Menangani Covid-19. Retrieved January 6, 2021, from https://kompaspedia.kompas.id/baca/paparan-topik/upaya-dankebijakan-pemerintah-indonesia-menangani-pandemi-covid-19

Lai, C.-C., Shih, T.-P., Ko, W.-C., Tang, H.-J., \& Hsueh, P.-R. (2020). Severe acute respiratory syndrome coronavirus 2 (SARS-CoV-2) and coronavirus disease-2019 (COVID-19): The epidemic and the challenges. International Journal of Antimicrobial Agents, 55(3), 105924. https://doi.org/10.1016/j.ijantimicag.2020.105924

Larson-Meyer, D. E., Woolf, K., \& Burke, L. (2018). Assessment of nutrient status in athletes and the need for supplementation. International Journal of Sport Nutrition and Exercise Metabolism. https://doi.org/10.1123/ijsnem.2017-0338

Lim, W., Damit, N., \& Aziz, A. (Eds.). (2014). Recommendations for optimal competitive exercise performance and effective training-induced adaptations when Ramadan fasting. In: Chtourou $H$, ed. Effects of Ramadan fasting on health and athletic performance. OMICS International. https://doi.org/10.4172/978-1-63278-030-0-031

Malonda, N. S. H., Dinarti, L. K., \& Pangastuti, R. (2012). Pola makan dan konsumsi alkohol sebagai faktor risiko hipertensi pada lansia. Jurnal Gizi Klinik Indonesia. https://doi.org/10.22146/ijen.18219

Memari, A. H., Kordi, R., Panahi, N., Nikookar, L. R., Abdollahi, M., \& Akbarnejad, A. (2011). Effect of Ramadan fasting on body composition and physical performance in female athletes. Asian Journal of Sports Medicine. https://doi.org/10.5812/asjsm.34754

Mielgo-Ayuso, J., Maroto-Sánchez, B., Luzardo-Socorro, R., Palacios, G., Palacios GilAntuñano, N., \& González-Gross, M. (2015). Evaluation of nutritional status and energy expenditure in athletes. Nutricion Hospitalaria. https://doi.org/10.3305/nh.2015.31.sup3.8770

Mitra, A. (2020). COVID-19 forces cancellation of top Olympiads, a few go online | Education News,The Indian Express. Retrieved January 6, 2021, from September website: https://indianexpress.com/article/education/covid-19-forces-cancellation-of-topolympiads-a-few-go-online-6562539/ 
Toni Kurniawan, Yetty Septiani Mustar, Agus Hariyanto, Indra Himawan Susanto, Anna Noordia

Moghadam, M. T., Taati, B., Paydar Ardakani, S. M., \& Suzuki, K. (2021). Ramadan Fasting During the COVID-19 Pandemic; Observance of Health, Nutrition and Exercise Criteria for Improving the Immune System. Frontiers in Nutrition, 7, 349. https://doi.org/10.3389/fnut.2020.570235

Nachvak, S. M., Pasdar, Y., Pirsaheb, S., Darbandi, M., Niazi, P., Mostafai, R., \& Speakman, J. R. (2019). Effects of Ramadan on food intake, glucose homeostasis, lipid profiles and body composition composition. European Journal of Clinical Nutrition, 73(4), 594600. https://doi.org/10.1038/s41430-018-0189-8

Nieman, D. C., \& Wentz, L. M. (2019). The compelling link between physical activity and the body's defense system. Journal of Sport and Health Science, 8(3), 201-217. https://doi.org/10.1016/j.jshs.2018.09.009

Niswah, M. (2016). Hubungan Antara Pola Makan Sehari - Hari Dan Gaya Hidup Sehat Dengan Prestasi Belajar Mahasiswa Pendidikan Biologi Uin Walisongo Semarang. Retrieved from http://eprints.walisongo.ac.id/id/eprint/5931/1/123811054.pdf

Noorbhai, M. (2013). Physical Activity During The Month Of Ramadaan Fasting. The Experiment, 7(June), 413-414.

Nurdini, D. A., \& Probosari, E. (2017). Tingkat kecukupan zat gizi dan kadar hemoglobin pada atlet sepakbola. Journal of Nutrition College. https://doi.org/10.14710/jnc.v6i1.16889

Png, W., Bhaskaran, K., Sinclair, A. J., \& Aziz, A. R. (2014). Effects of ingesting low glycemic index carbohydrate food for the sahur meal on subjective, metabolic and physiological responses, and endurance performance in Ramadan fasted men. International Journal of Food Sciences and Nutrition, 65(5), 629-636. https://doi.org/10.3109/09637486.2014.886187

Purcell. (2013). Sport nutrition for young athletes. Paediatr Child Health, 18 (2).

Puspitawati, I. D. (2019). PERILAKU AKTIVITAS OLAHRAGA PADA SAAT BULAN RAMADHAN. Jurnal Ilmu Keolahragaan. https://doi.org/10.26418/jilo.v2i2.35328

Ramadani, A. (2017). Hubungan Jenis, Jumlah dan Frekuensi Makan dengan Pola Buang Air Besar dan Kelihan Pencernaan Pada Mahasiswa Muslim Saat Puasa Ramadhan. Retrieved from https://repository.unair.ac.id/76619/2/KKC\%20KK\%20FKP.N.193$18 \% 20 \mathrm{Ram} \% 20 \mathrm{~h} \% 20$ SKRIPSI.pdf

Rizal, H., Hajar, M., \& Kuan, G. (2018). Training adaptations during Ramadan fasting: The FITT principle, progressive overload and recovery. Journal of Physical Health and Sports Medicine, 23-29. https://doi.org/10.36811/jphsm.2019.110003

Roberts, C., Gill, N., \& Sims, S. (2020). The Influence of COVID-19 Lockdown Restrictions on Perceived Nutrition Habits in Rugby Union Players. Frontiers in Nutrition, 7. https://doi.org/10.3389/fnut.2020.589737

Roy, J., Kuan, G., \& Tenenbaum, G. (2016). Sport Psychology Service Delivery in Malaysia: An Introduction to Common Cultural Norms and Experiences. Aspasp-Jpaspex Special Edition, 1(1), 22-29. 
Toni Kurniawan, Yetty Septiani Mustar, Agus Hariyanto, Indra Himawan Susanto, Anna Noordia

Russo, M., Fadda, J., \& Angioni, A. (2020). Nutrition, Sports, and Covid-19 Lockdown Impact on Young Competitive Artistic Swimming Athletes. Austin J Nutr Metab, 7(3), 5.

Shaw, G., Boyd, K. T., Burke, L. M., \& Koivisto, A. (2014). Nutrition for swimming. International Journal of Sport Nutrition and Exercise Metabolism, 24(4), 360-372. https://doi.org/10.1123/ijsnem.2014-0015

Shephard, R. J. (2012). The impact of Ramadan observance upon athletic performance. Nutrients, 4(6), 491-505. https://doi.org/10.3390/nu4060491

Stambulova, N. B., Schinke, R. J., Lavallee, D., \& Wylleman, P. (2020). The COVID-19 pandemic and Olympic/Paralympic athletes' developmental challenges and possibilities in times of a global crisis-transition. International Journal of Sport and Exercise Psychology, O(0), 1-10. https://doi.org/10.1080/1612197X.2020.1810865

Stearns, R. L., Scarneo-Miller, S. E., Huggins, R. A., Baker, L. B., Caterisano, T., Chiampas, G., ... Tripp, B. L. (2020). Return to Sports and Exercise during the COVID- 19 Pandemic: Guidance for High School and Collegiate Athletic Programs. 1-13.

Suzuki, K. (2019). Chronic Inflammation as an Immunological Abnormality and Effectiveness of Exercise. Biomolecules, 9(6), E223. https://doi.org/10.3390/biom9060223

Tayech, A., Mejri, M. A., Makhlouf, I., Mathlouthi, A., Behm, D. G., \& Chaouachi, A. (2020). Second Wave of COVID-19 Global Pandemic and Athletes' Confinement: Recommendations to Better Manage and Optimize the Modified Lifestyle. International Journal of Environmental Research and Public Health, 17(22), 8385. https://doi.org/10.3390/ijerph17228385

Thompson, L. J., Manore, M. M., \& Vaughan, A. L. (2017). Science of Nutrition, The: Pearson New International Edition: Pearson Higher Ed. Retrieved from https://www.pearson.com/uk/educators/higher-educationeducators/program/Thompson-Science-of-Nutrition-The-3rdEdition/PGM1040424.html

Welis, Wilda and Sazeli, R. M. (2013). Gizi untuk Aktifitas Fisik dan Kebugaran. Sukabina Press, Padang.

WHO EMRO. (2020). Dietary recommendations for the month of Ramadan. Who Emro, 1-3.

Wong, A. Y. Y., Ling, S. K. K., Louie, L. H. T., Law, G. Y. K., So, R. C. H., Lee, D. C. W., ... Yung, P. S. H. (2020). Impact of the COVID-19 pandemic on sports and exercise. AsiaPacific Journal of Sports Medicine, Arthroscopy, Rehabilitation and Technology. https://doi.org/10.1016/j.asmart.2020.07.006

Yousfi, N., Bragazzi, N. L., Briki, W., Zmijewski, P., \& Chamari, K. (2020). The COVID-19 pandemic: How to maintain a healthy immune system during the lockdown - a multidisciplinary approach with special focus on athletes. Biology of Sport, 37(3), 211216. https://doi.org/10.5114/biolsport.2020.95125 